\title{
Examination of Physical Activity and Life Quality Levels of University Students in Terms of Related Factors
}

\author{
Bekir Barış CIHAN ${ }^{1}$, Berkan BOZDAĞ ${ }^{2} \&$ Levent VAR $^{3}$ \\ ${ }^{1}$ University of Yozgat Bozok, School of Physical Education and Sports, Yozgat, Turkey \\ ${ }^{2}$ University of Amasya, School of Physical Education and Sports, Amasya, Turkey \\ ${ }^{3}$ University of Kırşehir Ahi Evran, School of Physical Education and Sports, Kırşehir, Turkey \\ Correspondence: Bekir Barış CİHAN, University of Yozgat Bozok, School of Physical Education and Sports, \\ Yozgat, Turkey. E-mail: bekirbaris_cihan@hotmail.com
}

Received: October 22, 2018

Accepted: November 18, 2018 Online Published: December 30, 2018

doi:10.5539/jel.v8n1p120

URL: https://doi.org/10.5539/jel.v8n1p120

\begin{abstract}
The purpose of this study is to examine the relationship between physical activity levels and life quality of Amasya University students. The universe of the study consists of university students studying in 6 faculties of the University of Amasya during the 2018-2019 academic year and the sample is composed of 331 (162 female, 169 male) university students. As data collection tools, in order to determine the level of physical activity (Craig, et al., 2003) by the improved validity and reliability study in Turkey (Öztürk, 2005) in order to determine the International Physical Activity Questionnaire. For the deremination of life quality, Fidaner's (1999) "World Health Organization Quality of Life Scale Short Form" was used. Data were analyzed using descriptive statistical methods, independent sample t-test and single factor variance analysis (One-Way ANOVA). As a result of the analyses; 262 students attending the research stated that the physical activity areas of the faculties were insufficient and 69 students stated that they were sufficient. When the body mass indexes of the participants were examined, it was found that the majority of $76.4 \%$ of the participants had normal BMI (Global Database on BMI, WHO, 2004) classification. A significant difference was found in the psychological and environmental dimensions of students' life quality in goodness of the students habiting at home. When it is classified according to physical activity score, it is seen that 65 students studying at the Faculty of Education have a high Met level, while 33 students studying at the Faculty of Medicine have low Met level. It was concluded that students with high levels of MET have higher total life quality scores than students at other levels of MET.
\end{abstract}

Keywords: physical activity, students, university, life quality

\section{Introduction}

Measurement of health status and quality of the individual from birth to death; It has been an important research topic for physicians, public health workers, statisticians, psychologists, sociologists and economists (Aldinç et al., 2004). For a pleasant and quality life, it can be said that health is the most vital element of human life.

For long years, research has been done to be healthy, slow down aging, energetic, live and positive. In the biological development that started with birth, it was desired to have the basic key of healthy and long life by keeping the life quality high, being resistant to psychological problems, living in healthy environment, feeding correctly and being active and controlling the factors that we have (Zorba, 2010).

People desire to have the basic key of healthy and long life; although it is considered that the life quality increases in the short term and increases the life quality in the short term, it increases the number of the immobile individuals in the long term and adversely affects the human health and decreases the life quality. The inactive lifestyle, non-ergonomic working conditions and the overload caused by stress cause deterioration in the physical, psychological and social health of individuals; resulting in a decrease in the physical activity levels and life quality of the individuals (Özer \& Baltac1, 2008).

Decreased physical activity and sedentary life habit create a great risk in terms of development of secondary health problems such as metabolic dysfunction, cardiovascular disease, low- bone density in the long term (Saygın \& Mengütay, 2004) 
Regular physical activity promotes life quality by strengthening psychological well-being and physical functioning (Vuori, 1998). Regular physical activity prevents the development of cardiovascular diseases, heart diseases, causes of some types of cancer, and in addition physical activity has a positive effect on blood pressure, lipid and lipidprotein profile, weight control, mental health and psychological well-being (Haskell et al., 2007).

Physical activity is beneficial to health at any age. Regular physical activity, healthy growth and development of children and young people, escaping from unwanted bad habits, socialization, the protection of adults from various chronic diseases or in the treatment of these diseases, supporting the elderly, an elderly aging period, in other words, increasing life quality throughout life and it can create a beneficial future (Bayrakçı, 2008). Research shows that physical activity is predominantly related to life quality with all other variables. At this point, it is possible to increase the life skills of young people by directing the interest and curiosity to sports and sports activities (Cihan \& Araç Ilgar, 2018). Regular physical activity promotes life quality by strengthening psychological well-being and physical functioning (Tessier et al., 2009).

Physical passiveness is a serious health risk not only for adults but also for children and adolescents. In addition to genetic, environmental and biological factors, the most important factor in the formation of chronic diseases is inactivity and malnutrition. It is observed that many chronic diseases that we are used to seeing in advanced ages have emerged in childhood as a result of the adoption of sedentary lifestyle. Therefore, increasing the movement in children and decreasing the time spent in the day during the infancy from the age of infancy has a special importance (Ministry of Health, 2012). There is a positive correlation between physical activity and life quality.

Health, which has an important place in the perception of life quality; our situational mood with our lifestyle and behavior is in a very close relationship with our environment. For this reason, the changes in our behaviors and our life in the time period caused many new dimensions in health. In this age, the rapid increase of urbanization, people moving their bodies less, socio-economic and cultural problems caused by distorted construction and factors causing psychological tension (noise, heavy traffic, etc.) have changed the way people have health problems (Yeniokatan, 2006). Life quality includes many areas of life and different values ranging from person to person. Life quality and its indicators such as physical and material well-being, satisfaction with activities in social life, leisure activities, psychological status, functional ability, emotional, spiritual and gender well-being, satisfaction in relations with family and friends, orientation towards future, (Telatar, 2007) In the socialization of the individual, communication with more people and coming over of the stress during the day and having more social support participation in physical activities taking place in free time share is very high (Zorba, 2008).

Quality of life and health-related life quality have been extensively evaluated in the literature. These evaluations are generally related to the measurement of physical functions and life quality (Hsiao, 2014). People need to have a quality life in order to be able to live happily, in harmony with themselves and their environment and in life satisfaction. The World Health Organization (WHO, 2004) has set the goal that individuals should have a healthy and better life quality as well as being productive in social, economic and spiritual terms (Ergen, 2011). Moreover; life quality, physical, psychological and social life views about the desired and obtained expectations include the harmony (Lustyk et al., 2004).

University life is a period in which individuals experience significant changes. In addition to vocational education, university education also causes changes in personality development, individual life and health behaviors. This change is especially important in terms of attitudes and behaviors in the field of health; because the attitudes and behaviors of the students about health individually affect themselves, their family and society in their present and future life. The level of health of the societies is measured by the majority of healthy individuals in the society (Ayaz, Tezcan, \& Akınc1, 2005). University experiences contribute to a health-related lifestyle related to their future, depending on their choices (Mathews, 2010). The aim of this study is to examine the physical activity level and life quality of university students in terms of social, psychological, environmental and health fields.

\section{Method}

In this research, a screening model which aims to describe an existing situation has been used. For this purpose, the relationship between the physical activity levels of my university students and my life quality has been examined. The screening method is a research approach that aims to describe a situation that exists in the past or the present. The event, the individual or the object which is included in the subject of research is tried to be defined as it is in its own conditions (Karasar, 2009; Saldamc1, 2016).

\subsection{Study Group}

This study was carried out totally with 331 students (162 female and 169 male) study in 6 faculties of the 
University of Amasya in 2018-2019 academic year.

Table 1. Detailed distribution and percentages of faculty types

\begin{tabular}{lll}
\hline & F & $\mathbf{\%}$ \\
\hline Faculty of Health Sciences & 42 & 12,7 \\
Medical Faculty & 39 & 11,8 \\
Faculty of Science and Letters & 85 & 25,7 \\
Faculty of Education & 65 & 19,6 \\
Architecture and Engineering Faculty & 53 & 16,0 \\
Technology Faculty & 47 & 14,2 \\
Total & 331 & 100,0 \\
\hline
\end{tabular}

In the Table 1 the detailed distribution of the faculties participating in our research is as follows; Faculty of Health Sciences 42 students (12.7\%), Faculty of Medicine 39 students (11.8\%), Faculty of Sicence and Letters 85 students (25.7\%), Faculty of Education 65 students (19.6\%), Faculty of Architecture and Engineering 53 students (16\%) The Faculty of Technology was 47 students (14.2\%).

\subsection{Data Collecting Tools}

International Physical Activity Assessment Questionnaire: International validity and reliability studies in order to collect data related to physical activity in this study (Craig et al., 2003); The validity and reliability study in Turkey performed by Öztürk (2005) and applied to university students by the International Physical Activity Questionnaire (International Physical Activity Questionnaire, IPAQ) short form is used. The International Physical Activity Assessment Questionnaire (IPAQ) was developed to determine the physical activity levels of participants aged 15-65 years (Craig, Marshall, Sjostrom, Bauman, \& Booth, 2003). IPAQ has been developed in order to obtain valid and comparable information about the physical activity level based on the individual reports on the daily physical activity in the international area. The tail ends suggested that the scale could show the prevalence of participation in physical activity in the society and for this purpose, the scale could be applied in many different cultures and environments (Tekkanat, 2008). In this study, the self-administered short form (IPAQ Short-Form) was used for the last 7 days. The IPAQ short form provides information about sitting, walking, moderately severe activities and time spent in severe activities (Öztürk, 2005). The calculation of the total score of the short form includes the sum of walking, moderately intensive activity, and intensive activity duration (minutes) and frequency (days) (IPAQ, 2006). Sitting score (sedentary behavior level) is calculated separately. In the evaluation of all activities, it is considered that each activity is performed for at least 10 minutes in a single time (Savc1 et al., 2006). A score is obtained as en MET-minute / week tek from these calculations. MET refers to the metabolic equivalent. A MET is 1 MET of body energy, which is equal to about $3.5 \mathrm{ml}$ of oxygen consumption. The more the body works during the activity, the higher the MET value. When making calculations for IPAQ Short-Form, minutes, days and MET values (multiples of resting oxygen consumption) are multiplied and a score is obtained as MET-minute / week IP (Savc1 et al., 2006).

Table 2. Values that are used for the analysis of IPAQ datum

\begin{tabular}{ll}
\hline Walking & $3.3 \mathrm{MET}$ \\
Medium Level Physical Activity & $4.0 \mathrm{MET}$ \\
Intensive Physical Activity & $8.0 \mathrm{MET}$ \\
Sitting & $1.5 \mathrm{MET}$ \\
\hline
\end{tabular}

According to the personal calculation, based on the MET calculation based on the frequency and intensity of physical activity, participants are classified in low, medium and high activity groups (Cengiz, 2007). The validity and reliability study of the IPAQ short form used in this study was conducted by Öztürk in 2005. The short and long forms of IPAQ provide repeatable and comparable data. The criterion validity for the short form $r=0.69$ was found as $r=0.30$ (Öztürk, 2005).

Quality of life Scale: In this study, the Turkish version of the WHOQOL-BREF scale, which was prepared by the World Health Organization with the participation of 15 cooperation centers, was applied to determine the life quality the participants. WHOQOL-BREF scale includes; physical area, psychological field, social relations and environment. The WHOQOL-BREF scale is completed by the participant and in the last 15 days. The scale 
includes closed-ended questions in accordance with the Likert scale. The scale, which has been studied in different cultures, can be applied to adult age group and it is accepted as a reliable and valid measurement tool of life quality (Fidaner, 1999).

The averages of each question are used to calculate the field scores. Then, the average score is multiplied by 4 to make it comparable with the WHOQOL-100 scale. In calculating the points, first of all the answers given to all questions should be checked between 1 and 5 and if there is a different value, they should be changed to empty (Telatar, 2007).

Cronbach alpha values calculated for the internal consistency of the scale were 0.83 in the physical area, 0.66 in the psychological field, 0.53 in the social relations area, and 0.73 in the environmental area, and 0.73 in the national environment area. For the calculation of test-retest reliability, the Pearson Coefficients calculated for each question ranged between 0.57 and 0.81 (Fidaner, et al., 1999).

Table 3. WHOQOL-BREF Sub dimensions and questions that encapsulate the scale

\begin{tabular}{ll}
\hline Fields & Questions \\
\hline Physical Field & $3,4,10,15,16,17,18$ \\
Spiritual Field & $5,6,7,11,19,26$ \\
Social Field & $20,21,22$ \\
Environment Field & $8,9,12,13,14,23,24,25$ \\
Enviromental Field TR & $8,9,12,13,14,23,24,25,27$ \\
\hline
\end{tabular}

\subsection{Procedure}

Personal information form used as data collection tools, IPAQ short form and WHOQOL-BREF scales were applied to 331 students by the researcher between March-April 2018.

\subsection{Data Analysis}

The SPSS 22 program was used to evaluate the research data. Prior to statistical analysis of the data obtained from study group, they must be prepared for analysis. To this aim, researchers must pay attention to kurtosis and skewness coefficients (Simşek, 2007). Skewness coefficient is 0 in the normal distribution. A negative skewness coefficient indicates a right-skewed distribution while a positive skewness coefficient indicates a left-skewed distribution. Similarly, kurtosis coefficient is 0 in the normal distribution. A positive kurtosis coefficient indicates a leptokurtic distribution, while a negative kurtosis coefficient indicates a platykurtic distribution (http 1). Because kurtosis and skewness coefficients vary between (+-2 and +-7), it can be stated that the data display a normal distribution (West et al., 1995; Sencan, 2005; Simşek, 2007).

It was found out in the present study that skewness and kurtosis coefficient values related to the data of the present study vary between $-0.056 / 1.311$ and $-0.080 / 3.440$ respectively. These results demonstrate that the data display a normal distribution, and parametric tests were used in the statistical analysis. The data were analyzed using descriptive statistical methods, independent sample t-test and single factor variance analysis (One-Way ANOVA). Significances was shown in $\mathrm{p}<0.05$ and its levels.

\section{Results}

In this section, firstly, descriptive statistics about the students who formed the study group were included and then the research hypotheses were tested. Table 4 contains information on the demographic characteristics of the participants. 
Table 4. Demographical information

\begin{tabular}{|c|c|c|c|}
\hline & & f & $\%$ \\
\hline \multirow{3}{*}{ Gender } & Female & 162 & 48.9 \\
\hline & Male & 169 & 51.1 \\
\hline & Total & 331 & 100.0 \\
\hline \multirow{6}{*}{ Faculty } & Health Sciences & 42 & 12.7 \\
\hline & Medicine & 39 & 11.8 \\
\hline & Sicence and Letters & 85 & 25.7 \\
\hline & Education & 65 & 19.6 \\
\hline & Architecture and Engineering & 53 & 16.0 \\
\hline & Technology & 47 & 14.2 \\
\hline \multirow{3}{*}{ Marital Status } & Married & 16 & 4.8 \\
\hline & Single & 315 & 95.2 \\
\hline & Total & 331 & 100.0 \\
\hline \multirow{10}{*}{ Age } & 18 & 6 & 1.8 \\
\hline & 19 & 21 & 6.3 \\
\hline & 20 & 66 & 19.9 \\
\hline & 21 & 83 & 25.1 \\
\hline & 22 & 79 & 23.9 \\
\hline & 23 & 50 & 15.1 \\
\hline & 24 & 22 & 6.6 \\
\hline & 25 & 2 & .6 \\
\hline & 26 & 2 & .6 \\
\hline & Total & 331 & 100.0 \\
\hline \multirow{3}{*}{ Habiting Place } & Dormitory & 199 & 60.1 \\
\hline & Home & 132 & 39.6 \\
\hline & Total & 331 & 99.7 \\
\hline \multirow{3}{*}{ Sufficient Physical Activity } & Yes & 69 & 20.8 \\
\hline & No & 262 & 79.2 \\
\hline & Total & 331 & 100.0 \\
\hline \multirow[b]{6}{*}{ BMI } & Weak & 20 & 6.0 \\
\hline & Normal & 253 & 76.4 \\
\hline & Overweight 1 & 50 & 15.1 \\
\hline & Overweight 2. & 6 & 1.8 \\
\hline & Overweight 3. & 2 & .6 \\
\hline & Total & 331 & 100.0 \\
\hline
\end{tabular}

When the Table 4 is examined; the study consisted of 331 university students (162 females and 169 males). Students live in 132 residences in 199 dorms according to their place of residence. $79 \%$ of the students suggested that there were not enough physical activity areas in the faculties. When the body mass indexes of the participants were examined, the majority of $76.4 \%$ of the participants had normal BMI (Global DAbase on Bm1, WHO 2004) classification.

Table 5. Results related to sub dimensions of life quality of participants' habiting places (t-test)

\begin{tabular}{|c|c|c|c|c|c|c|c|}
\hline & Habitation & $\mathrm{N}$ & Aver. & Ss & $\mathrm{t}$ & Df & $\mathrm{p}$ \\
\hline \multirow{2}{*}{ Physical Field } & Dorm & 199 & 15.02 & 2.41 & \multirow{2}{*}{-.501} & \multirow{2}{*}{328} & \multirow{2}{*}{.617} \\
\hline & Home & 131 & 15.15 & 2.35 & & & \\
\hline \multirow{2}{*}{ Spiritual Field } & Dorm & 199 & 13.21 & 1.63 & \multirow{2}{*}{-2.34} & \multirow{2}{*}{328} & \multirow{2}{*}{$.020^{*}$} \\
\hline & Home & 131 & 13.62 & 1.43 & & & \\
\hline \multirow{2}{*}{ Social Field } & Dorm & 199 & 13.44 & 3.28 & \multirow{2}{*}{-1.00} & \multirow{2}{*}{328} & \multirow{2}{*}{.317} \\
\hline & Home & 131 & 13.81 & 3.30 & & & \\
\hline \multirow{2}{*}{ Enviromental Field } & Dorm & 199 & 12.80 & 2.01 & \multirow{2}{*}{-2.44} & \multirow{2}{*}{328} & \multirow{2}{*}{$.015^{*}$} \\
\hline & Home & 131 & 13.45 & 2.77 & & & \\
\hline
\end{tabular}

When Table 5 is examined; significant differences were found in the psychological and environmental dimensions of students' life quality in favor of students habiting at home $(t(328)=-2.34 ; p<0.05)$. 
Table 6. Distribution of faculties depending on Met level

\begin{tabular}{|c|c|c|c|c|c|c|c|c|}
\hline Faculties & & Health Sciences & Medicine & Science and Letters & Education & Architecture and Eng. & Technology & Total \\
\hline \multirow[t]{2}{*}{ MET Level Low } & $\mathrm{N}$ & 8 & 4 & 16 & 5 & 9 & 10 & 52 \\
\hline & $\%$ & 15.4 & 7.7 & 30.8 & 9.6 & 17.3 & 19.2 & 100.0 \\
\hline \multirow{2}{*}{ MET Level Mid } & $\mathrm{N}$ & 31 & 33 & 65 & 50 & 42 & 35 & 256 \\
\hline & $\%$ & 12.1 & 12.9 & 25.4 & 19.5 & 16.4 & 13.7 & 100.0 \\
\hline \multirow[t]{2}{*}{ MET Level High } & $\mathrm{N}$ & 3 & 2 & 4 & 10 & 2 & 2 & 23 \\
\hline & $\%$ & 13.0 & 8.7 & 17.4 & 43.5 & 8.7 & 8.7 & 100.0 \\
\hline \multirow[t]{2}{*}{ Total } & $\mathrm{N}$ & 42 & 39 & 85 & 65 & 53 & 47 & 331 \\
\hline & $\%$ & 12.7 & 11.8 & 25.7 & 19.6 & 16.0 & 14.2 & 100.0 \\
\hline
\end{tabular}

Table 6. When the Total Met Scores of the Faculties are analyzed by Level, it is seen that while 65 (43.5\%) students who study at the faculty of education have a high Met level, 33 (7\%) students who study in the Faculty of Medicine have a low Met level.

Table 7. Descriptive results of total life quality points in Met values

\begin{tabular}{llll}
\hline & $\mathrm{N}$ & $\mathrm{X}$ & S.S. \\
\hline Low & 52 & 13.5147 & 2.04216 \\
Middle & 256 & 13.8123 & 1.67357 \\
High & 23 & 14.0055 & 2.50609 \\
Total & 331 & 13.7790 & 1.80082 \\
\hline
\end{tabular}

When the descriptive analyzes in Table 7 are examined, it is seen that the students with high levels of MET have higher total life quality compared to the students at other levels. To see if this difference was significant or not the One Way ANOVA test was used. The results are given in Table 8 below.

Table 8. Differences in the levels of met values of quality of life of participants (ANOVA)

\begin{tabular}{llllll}
\hline & Squares Total & sd & Squares Average & F & P \\
\hline Inter Groups & 5.099 & 2 & 2.55 & .785 & .457 \\
In-Group & 1065.077 & 328 & 3.25 & & \\
Total & 1070.176 & 330 & & & \\
\hline
\end{tabular}

Table 8 is examined; There was no statistically significant difference between total life quality scores and physical activity scale. $(\mathrm{F}(2.328))=0.79$

Table 9. Frequency distribution of sufficient physical activity opportunities of faculties

\begin{tabular}{lllll}
\hline & & Sufficient & Total \\
& & Yes & No & \\
\hline Health Sciences & $\mathrm{N}$ & 8 & 34 & 42 \\
Medicine & $\%$ & 19.00 & 81.00 & 100 \\
& $\mathrm{~N}$ & 8 & 31 & 39 \\
Science and Letters & $\%$ & 20.50 & 79.50 & 100 \\
& $\mathrm{~N}$ & 16 & 69 & 85 \\
Education & $\%$ & 18.80 & 81.20 & 100 \\
Architecture and Engineering & $\mathrm{N}$ & 9 & 56 & 65 \\
& $\%$ & 13.80 & 86.20 & 100 \\
Technology & $\mathrm{N}$ & 13 & 40 & 53 \\
& $\%$ & 24.50 & 75.50 & 100 \\
Total & $\mathrm{N}$ & 15 & 32 & 47 \\
& $\%$ & 31.90 & 68 & 100 \\
& $\mathrm{~N}$ & 69 & 262 & 331 \\
\end{tabular}


Table 9 is examined; 262 students (79.2\%) stated that the physical activity areas of the faculty were inadequate and 69 students $(20.80 \%)$ stated that they were sufficient. While the physical activity variable is insufficient in terms of the science and letters faculty $(81.2 \%)$ and the faculty of health sciences $(81 \%)$, the students of the faculty of education. $86.2 \%$ stated that the highest ratio of physical activity areas was insufficient.

Table 10. Results related to faculties' life quality of physical field dimension (ANOVA)

\begin{tabular}{|c|c|c|c|c|c|c|c|c|c|c|}
\hline & Group & $\mathbf{N}$ & Average & Ss & Value & Squares Total & sd & Squares Average & $\mathbf{F}$ & $\mathbf{p}$ \\
\hline \multirow[t]{7}{*}{ Physical Field } & Health Sciences & 42 & 14.73 & 2.59 & Intergroups & 19.60 & 5 & 3.92 & .687 & .634 \\
\hline & Medicine & 39 & 14.83 & 2.37 & In group & 1854.77 & 325 & 5.70 & & \\
\hline & Science and letters & 85 & 15.21 & 2.37 & Total & 1874.37 & 330 & & & \\
\hline & Education & 65 & 15.12 & 2.14 & & & & & & \\
\hline & Architecture and Engineering & 53 & 14.88 & 2.88 & & & & & & \\
\hline & Technology & 47 & 15.50 & 1.93 & & & & & & \\
\hline & Total & 331 & 15.08 & 2.38 & & & & & & \\
\hline
\end{tabular}

When we consider Table 10, there is no statistically significant difference found depending on physical life quality scale of faculties. $(\mathrm{F}(2.325)=0.69)(\mathrm{p}>0.05)$.

Table 11. Descriptive results of total life quality points in classification of BMI

\begin{tabular}{llll}
\hline Classification & N & X & SS \\
\hline Weak & 20 & 13.2467 & 1.73169 \\
Normal & 253 & 13.9700 & 1.65536 \\
Overweight 1 & 50 & 13.0849 & 1.79634 \\
Overweight 2 & 6 & 12.0503 & 1.47994 \\
Overweight 3 & 2 & 11.9921 & 1.40299 \\
Total & 331 & 13.7459 & 1.72459 \\
\hline
\end{tabular}

When the descriptive analyzes are examined in the Table 11, it is seen that the total quality of life scores of the students with higher levels of BMI are higher than the other group of students' points.

Table 12. Results of life quality according to faculties (ANOVA)

\begin{tabular}{|c|c|c|c|c|c|c|c|c|c|c|}
\hline & Group & $\mathbf{N}$ & Average & Ss & Value & Squares Total & sd & Squares Average & $\mathbf{F}$ & $\mathbf{p}$ \\
\hline \multirow[t]{8}{*}{ Spiritual Field } & Health Sciences & 42 & 13.16 & 1.26 & Intergroups & 9.66 & 5 & 1.93 & .789 & .558 \\
\hline & Medicine & 39 & 13.47 & 1.83 & In-Group & 795.52 & 325 & 2.44 & & \\
\hline & Science and Letter & 85 & 13.29 & 1.68 & Total & 805.18 & 330 & & & \\
\hline & Faculty & & & & & & & & & \\
\hline & Education & 65 & 13.68 & 1.41 & & & & & & \\
\hline & $\begin{array}{l}\text { Architecture and } \\
\text { Engineering }\end{array}$ & 53 & 13.33 & 1.57 & & & & & & \\
\hline & Technology Faculty & 47 & 13.28 & 1.55 & & & & & & \\
\hline & Total & 331 & 13.38 & 1.56 & & & & & & \\
\hline
\end{tabular}

Table 12 indicates that there is no statistically significant difference between the psychological dimension of life quality and faculties ( $>00.05$ ). 
Table 13. Results related to faculties' life quality depending on enviromental field dimension (ANOVA)

\begin{tabular}{|c|c|c|c|c|c|c|c|c|c|c|c|}
\hline & Group & $\mathbf{N}$ & ort & Ss & Values & Squares Total & sd & Squares Average & $\mathbf{F}$ & $\mathbf{p}$ & tukey \\
\hline \multirow[t]{12}{*}{ Enviromental Field } & (1) Health & 42 & 12.25 & 1.98 & Intergroups & 86.70 & 5 & 17.34 & 3.22 & .007 & $1-5$ \\
\hline & Sciences & & & & & & & & & & \\
\hline & (2) Medicine & 39 & 13.06 & 1.86 & In-Group & 1750.16 & 325 & 5.38 & & & \\
\hline & (3) Science and & 85 & 12.61 & 2.29 & Total & 1836.87 & 330 & & & & \\
\hline & Letters Faculty & & & & & & & & & & \\
\hline & (4) Education & 65 & 13.55 & 2.29 & & & & & & & \\
\hline & (5) Faculty of & 53 & 13.76 & 3.05 & & & & & & & \\
\hline & Architecture and & & & & & & & & & & \\
\hline & Engineering & & & & & & & & & & \\
\hline & (6) Technology & 47 & 13.17 & 2.06 & & & & & & & \\
\hline & Faculty & & & & & & & & & & \\
\hline & Total & 331 & 13.06 & 2.36 & & & & & & & \\
\hline
\end{tabular}

According to Table 13, the life quality of the Faculties was found statistically different in terms of environmental area size. In order to determine which group the difference is caused by in the the tukey test; A statistically significant difference was found between the students of Faculty of Health Sciences $(X=12.25)$ and Faculty of Architecture and Engineering (13.76) (in favor of Faculty of Architecture and Engineering) (F (5.325) = 3.22; p $<0.05)$. There was no statistically significant difference found between other faculties.

Table 14. Results of total life quality points of faculties (ANOVA)

\begin{tabular}{llllllllll}
\hline & Group & N & Average & Ss & Values & Squares Total & Sd & Squares Average & F \\
\hline Total Life Quality & Health sciences Faculty & 42 & 13.21 & 1.73 & Intergroups & 23.14 & 5 & 4.62 & \\
& Faculty of Medicine & 39 & 13.66 & 1.71 & In-Group & 1047.03 & 325 & 3.22 & \\
& Faculty of Science and & 85 & 13.68 & 1.86 & Total & 1070.17 & 330 & .211 \\
& Letters & & & & & & & \\
& Faculty of Education & 65 & 14.02 & 1.72 & & & & \\
& Faculty of Architecture & 53 & 13.96 & 2.06 & & & & \\
& an Engineering & & & & & & & \\
& Technology Faculty & 47 & 14.02 & 1.58 & & & & \\
& Total & 331 & 13.78 & 1.80 & & & & \\
\hline
\end{tabular}

When Table 14 is examined, there was no statistically significant difference found between total life quality scores of faculties $(\mathrm{p}>0.05)$.

\section{Discussion}

In this study, it is thought that there is a significant relationship between the physical activity levels and quality of life of university students; When the descriptive statistics of the answers given by the participants were examined, it was found that while $65(43.5 \%)$ of the students in the Faculty of Education had a high Met level according to their physical activity score, 33 students (7\%) who study at Medical Faculty have low level of MET. The fact that the students in the Faculty of Education have high met scores, physical education teacher students who continue their education in the Faculty of Education are thought to have more physical activities than the students studying in other departments due to their curriculum and personal tendencies.

When the environmental area dimension of quality of life was examined according to faculties, a statistically significant difference was found in favor of Faculty of Architecture between Faculty of Health Sciences and Faculty of Architecture. These results are in parallel with the study of Cengiz (2007) and Ebem (2007). It can be said that the universities where the research is carried out have different facilities, activities and facilities to strengthen the participation in physical activity with different physical conditions. In this context, it is thought that the faculty of health sciences is far from the city center and the engineering and architecture faculties are in the same position with the city center and have more opportunities to meet the needs of the environmental area and students.

There was a significant difference found in the psychological and environmental dimensions of the quality of life of the students participating in the study in favor of the students residing in the home. This result was reported by Brown et al. (2003), Tekkanat's (2008) study show parallelism with the findings. In the other students, all areas of quality of life were significantly higher than those living in the dormitory. This finding can be interpreted that 
the quality of life of the students staying at home is higher. It can be thought that the students staying at the dormitory have less satisfaction level than the ones living in the dormitories, and the conditions in the dormitory should be examined. In addition, the fact that students staying at home feel more free in creating their own lifestyle may have led to this result.

When the descriptive results of the values of total life quality scores are examined, it is seen that the students with higher level of MET value have higher total quality of life compared to the students of other met levels. Similarly, (McAuley et al., 2008; Koçak \& Özkan, 2009; Hakkinen et al., 2010; Cevada et al., 2012; Yıldırım, \& Bayrak, 2017) found a significant relationship between the increase in physical activity and self-confidence, and overall quality of life in terms of mental status. Vural et al., (2010) reported that the levels of physical activity make contribution in the quality of life.

While 262 students (79.2\%) stated that the physical activity areas of the faculty were insufficient, 69 students $(20.80 \%)$ stated that they were sufficient, while the Faculty of Science and Letters $(81.2 \%)$ and the Faculty of Health Sciences (81\%) were insufficient. Students of the Faculty of Education $86.2 \%$ stated that the highest ratio of physical activity areas is insufficient. Studies at different times and in different places support our findings (Jenkinson \& Benson, 2010; Antoine 2012; Demirhan et al., 2014; Sterdt et al., 2015; Y1ldırım, 2018). As a result of the results of the study, the Faculty of Science and Letters Faculty and the Faculty of Health Sciences ( $82 \%)$ respond to the same ratio of both faculties thought to be due to being within the same campus, inadequacy of activity areas at the highest rate (86\%) inadequate finding the body within the faculty of education As a result of the course program and personal tendencies, students who are studying teaching education are expected to have more expectations than students studying in other departments.

In our study, according to BMI classification, apporximately $17 \%$ of the students were found as over weight. While the study of Avşar et al. (2013), shows parallelism with our study (16.5\%), in the research of Özdoğan et al. (2012), they emphasized that $9.2 \%$ of the students were over weight. In a study of Hakkinen et al. (2010) applied on 727 male individuals, a strong relation was found between the activity levels and life qaualities of individuals with average and higher level of physical activity. It was found that physical activity levels were insufficient, but this was not related to the quality of life of individuals (Vural et al., 2010). Cevada et al. (2012) found that in a study on 15 to 18 years of age, 15 active gymnasts, 15 old athletes and 30 sedentaries; reported that sports contribute to a better quality of life with a more flexible body structure. Edwards et al. (2004), in their study with university students, stated that the quality of life of individuals who participate in sportive activity is high. In another study in which the mental well-being of different exercise types were evaluated, 60 hockey players and 27 healthy life club athletes and 111 sedentary students were compared among the university students (Edwards et al., 2004)

According to the results obtained in the research; it was stated that the physical activity areas of the students attending all faculties were insufficient. The majority of the students were determined to be normal according to the BMI (Global Database on BMI, WHO, 2004) classification. A significant difference was found in the psychological and environmental dimensions of the quality of life of the students participating in the study in favor of the students habiting in the home. When we examined the total quality of life scores on the basis of faculties, there was no statistically significant difference in terms of total quality of life. When the descriptive analyzes were examined, it was determined that the students with high levels of MET had higher total quality of life scores compared to the students at other met levels. A positive and strong relationship was found between the students with higher levels of MET scores compared to the students at other levels. In this context, programs that encourage and increase the participation of university students in physical activity should be organized.

\section{References}

Aldinç, H., Aytar, B., Demetçi, M. E., Seçen, A. E., Şahin, A., \& Yılmaz, H. (2004). Ankara İlinde Seçilen Birinci Basamak Sağllk Kuruluşlarına Başvuran 18 Yaş ve Üzeri Kişilerin Medikososyal Özelliklerine Göre Yaşam Kalitelerinin Karşılaşttrılması. Master's Thesis, Gazi Üniversitesi, Ankara.

Antoine, M. (2012). Educators Perceptions of School Barriers to Physical Education and Physical Activity. Doctoral Dissertation. George Mason University. Available from Proquest Dissertations and Theses Database. (UMI No. 3513413).

Avşar, P., Kazan, E. E., \& Pınar, G. (2013). Üniversite Öğrencilerinin Beslenme Alışkanlıkları İle Obezite Ve Kronik Hastalıklara İlişkin Risk Faktörlerinin İncelenmesi. Yıldırım Beyazıt Üniversitesi Hemşirelik E-Dergisi, 1(1), 38-46.

Ayaz, S., Tezcan, S., \& Akıncı, F. (2005). Hemşirelik Yüksekokulu Öğrencilerinin Sağlığı Geliştirme 
Davranışları. Cumhuriyet Üniversitesi Hemşirelik Yüksek Okulu Dergisi, 9(2), 26-34.

Bayrakçı, Y. V. (2008). Yetişkinlerde Fiziksel Aktivite. Klasmat Matbaacılık: Ankara.

Brown, D. W., Balluz, L. S., \& Heath, G. W. (2003). Associations Between Recommended Levels Of Physical Activity And Health-Related Quality Of Life. Findings From The 2001. Behavioral Risk Factor Surveillance System (BRFSS) Survey. Prev Med., 37, 520-528. https://doi.org/10.1016/S0091-7435(03)00179-8

Cengiz, C. (2007). Orta Doğu Teknik Üniversitesi Öğrencilerinin Fiziksel Aktivite Düzeyleri Ve Egzersiz Davranışının Değişim Basamakları. Yüksek lisans tezi, Orta Doğu Teknik Üniversitesi, Ankara.

Cengiz, C. (2007). Physical Activity and Exercise Stages of Change Levels of Middle East Technical University Students. Master's Thesis, Department of Physic al Education and Sports, Ankara.

Cevada, T., Cerqueira, L. S., De Moraes, H. S., \& Dos Santo, T. M. (2012). Relationship between sport, resilience, quality of life, and anxiety. Rev. Psiquiatr. Clín, 39(3), 85-89. https://doi.org/10.1590/S0101-60832012000300003

Cihan, B. B., \& Araç Ilgar, E. (2018). Spor Yapan ve Spor Yapmayan (Sedanter) Lise Öğrencilerinin Meraklılık Düzeylerinin Belirlenmesi. Ahi Evran Üniversitesi Kırşehir Eğitim Fakültesi Dergisi, 19(2), 1649-1660.

Craig, C. L., Marshall, A. L., Sjostrom, M., Bauman, A. E., \& Booth, M. L. (2003) International physical activity questionnaire: 12-country reliability and validity. Medicine and Science in Sports and Exercise, 35, 1381-1395. https://doi.org/10.1249/01.MSS.0000078924.61453.FB

Demirhan, G., Bulca, Y., Saçlı, F., \& Kangalgil, M. (2014). Beden Eğitimi Öğretmenlerinin Uygulamada Karşıllaştıkları Sorunlar ve Çözüm Önerileri. Hacettepe Üniversitesi Eğitim Fakültesi Dergisi, 29(2), 57-68.

Ebem, Z. (2007). Health Promoting Behaviors and Exercise Stages of Change Levels of Students. Master's Thesis, Transation To University.

Edwards, D. J., Edwards, D. S., \& Basson, C. J. (2004). Psychological Well-Being and Physical Self-Esteem In Sport And Exercise. International Journal of Mental Health Promotion, 6(1), 25-32. https://doi.org/10.1080/14623730.2004.9721921

Ergen, A., Tanrıverdi, O., Kumbasar, A., Arslan, E., \& Atmaca, D. (2011). Sağlık Personelinin Yaşam Kalitesi Üzerine Kesitsel Bir Çalışma. Medical Bulletin of Haseki / Haseki Tip Bülteni, 49(1). Retrieved from http://cms.galenos.com.tr/Uploads/Article_6100/14-19.pdf

Fidaner, H., Elbi, H., Fidaner, C., Eser, S. Y., Eser, E., \& Göker, E. (1999). Yaşam Kalitesinin Ölçülmesi. Whoqol-100VeWhoqol-Bref, 3PDergisi, 5-13. Retrieved from http://psikiyatridizini.net/articles.aspx journalid $=12 \&$ year $=1999 \&$ volume $=7 \&$ number $=\mathrm{Ek} \% 202$

Global Database on BMI, WHO. Retrieved from http://www.who.int/ bmi/index.jsp?introPage=intro_3.html

Hakkinen, A., Rinne, M., Vasankari, T., Santtila, M., Hakkinen, K., \& Kyrölainen, H. (2010). Association of physical fitness with health-related quality of life in Finnish young men. Health and Quality of Life Outcomes, 8, 15. https://doi.org/10.1186/1477-7525-8-15

Haskell, L. W., Lee, M. I., Pate, R. R., Powell, E. K., Blair, N. S., Franklin, A. B., .. Bauman, A. (2007). Physical Activity and Public Health: Updated Recommendation for Adults from the American College of Sports Medicine and the American Heart Association. Medicine and Science in Sports and Exercise, 39(8), 1423-1434. https://doi.org/10.1249/mss.0b013e3180616b27

Hsiao, Y.-Y., Wu, C. H., \& Yao, G. (2014). Convergent and Discriminant Validity of the Wooqol-Bref Using A Multitrait-Multimethod Approach. Social Indicators Research, 116(3), 971-978. https://doi.org/10.1007/s11205-013-0313-z

Jenkinson, K. A., \& Benson, A. C. (2010). Barriers to Providing Physical Education and Physical Activity in Victorian State Secondary Schools. Australian Journal of Teacher Education, 35(8), 1-17. https://doi.org/10.14221/ajte.2010v35n8.1

Karasar, N. (2009). Bilimsel Araştırma Yöntemi. Ankara: Nobel Yayın Dağıtım.

Koçak, Ü. F., \& Özkan, F. (2008). Yaşlılarda Fiziksel Aktivite Düzeyi ve Yaşam Kalitesi. 10. Uluslararası Spor Bilimleri Kongresi. Bolu.

Lustyk, K. B., Widman, L., Paschane, A. A., \& Olson, K. C. (2004). Physical Activity and Quality Of Life: Assessing the Influence of Activity Frequency, Intensity, Volume, and Motives. Behavioral Medicine, 30, 
124-131. https://doi.org/10.3200/BMED.30.3.124-132

Mathews, D. (2008). Assessing Sleep Quality In Young Adult Collage Students Aged 18-24 In Relation To Quality Of Life And Anthropometrics. Master of Sicience Thesis, B. S. University Of Maine.

McAuley, S. E., Doerksen, S. E., Morris, K., Motl, R. W., Hu, L., \& Wojcicki, T. R. (2008). Pathways from Physical Activity to Quality of Life in Older Women. Ann. Behav. Med., 36(1), 13-20. https://doi.org/10.1007/s12160-008-9036-9

Özer, D., \& Baltacı, G. (2008). İş Yerinde Fiziksel Aktivite, Fiziksel Aktivite Bilgi Serisi. Ankara: Klasmat Matbaacilik.

Öztürk, M. (2005). Üniversitelerde Ĕ̈itim-Öğretim Gören Öğrencilerde Uluslararası Fiziksel Aktivite Anketinin Geçerliliği Ve Güvenirlik Ve Fiziksel Aktivite Düzeylerinin Belirlenmesi. Yüksek Lisans Tezi, Hacettepe Üniversitesi, Ankara.

Saldamc1, A. (2016). Bilimsel Araştırma Ve Sunum Teknikleri, Detay Yayıncılık, Ankara.

Savc1, B. A. (2006). Kanserli Hastalarda Yaşam Kalitesini ve Sosyal Destek Düzeyini Etkileyen Faktörler. Yüksek Lisans Tezi, Atatürk Üniversitesi, Erzurum.

Saygın, Ö., \& Mengütay, S. (2004). Kız Ve Erkek Çocukların Fiziksel Aktivite Düzeyleri Ve Fiziksel Aktivite Yoğunluklarının Değerlendirilmesi. Spor ve Tip Dergisi, 12(1), 13-16.

Sterdt, E., Liersch, S., \& Henze, V. (2015). Implementing Daily Physical Education in Primary School Potentials and Barriers from the Involved Actor's Point of View. Gesundheltswesen, 77(4), 269-275.

Tekkanat, Ç. (2008). Öğretmenlik Bölümünde Okuyan Öğrencilerde Yaşam Kalitesi Ve Fiziksel Aktivite Düzeyleri. Yüksek lisans tezi, Denizli.

Telatar, T. G. (2007). Sanayide Çalışan 20-24 Yas Grubu Erkeklerin Yaşam Kalitesi Ve Riskli Davranışlarının Belirlenmesi. Hacettepe Üniversitesi, Master of Sicience Thesis, Ankara

Tessier, S., Vuillemin, A., Bertrais, S., Boini, S., Bihan, E. L., Oppert, J. M., ... Briançon, S. (2009). Association Between Leisure-Time Physical Activity And Health-Related Quality Of Life Changes Over Time. Preventive Medicine, 44(3), 202-208. https://doi.org/10.1016/j.ypmed.2006.11.012

Vuori, I. (1998). Does Physical Activity Enhance Health? Patient Education and Counseling, 33, 95-103. https://doi.org/10.1016/S0738-3991(98)00014-7

Vural, Ö., Eler, S., \& Güzel, N. A. (2010). Masa Bazı Çalışanlarda Fiziksel Aktivite Düzeyi Ve Yaşam Kalitesi İlişkisi. Spormetre Beden Ë̆itimi ve Spor Bilimleri Dergisi, $8(2), \quad 69-75$. https://doi.org/10.1501/Sporm_0000000178

WHO. (2004). Appropriate Body-Mass Index for Asian Populations And Its Implications For Policy And Intervention Strategies. The Lancet, 157-163.

Yeniokatan, İ. (2006). Çevre Yerleşim Yeri Hanelerinin Yaşam Kalitesi Ve Kentsel Yaşama Katılımı. Hacettepe Üniversitesi, Yüksek Lisans Tezi, Ankara.

Y1ldırım, M. (2018). Investigation of Physical Activity Levels of Physical Education and Sports School Students, Asian Journal of Education and Training, 4(4), 347-355. https://doi.org/10.20448/journal.522.2018.44.380.390

Yıldırım, M., \& Bayrak, C. (2017). Üniversite Öğrencilerinin Spora Dayalı Fiziksel Aktivitelere Katılımları ve Yaşam Kalitelerinin Akademik Başarı ve Sosyalleşme Üzerine Etkisi (Eskişehir Osmangazi Üniversitesi Örneği), Hacettepe Üniversitesi Eğitim Fakültesi Dergisi.

Zorba, E. (2008). Yaşam Boyu Spor Ve Olimpiyatlar, EuroAsia Sport News, 94-98.

Zorba, E. (2010). Yaşam Kalitesi Ve Fiziksel Aktivite. 10. Uluslararası Spor Bilimleri Kongresi, Bolu.

\section{Copyrights}

Copyright for this article is retained by the author, with first publication rights granted to the journal.

This is an open-access article distributed under the terms and conditions of the Creative Commons Attribution license (http://creativecommons.org/licenses/by/4.0/). 